\title{
ANÁLISIS
}

\section{China's Fiscal Decentralization: consequences for the promotion of local development}

DOI: $10.32870 /$ mycp.v11i31.298

Beatriz Carrillo García*

\begin{abstract}
Fiscal decentralization has been an integral part of China's decentralization process, which successfully promoted local government entrepreneurialism. But while fiscal reform gave governments increasing authority over local revenue, they have also faced increasing expenditure responsibilities. This article aims to analyze the processes of fiscal decentralization that was put in place in the early 1980s, and to elucidate on the rationale and consequences of that process.

Key words. Fiscal decentralization, local government, central government, regional disparity, fiscal income and expenditures, reform.
\end{abstract}

\section{Resumen}

La descentralización fiscal ha sido parte integral del proceso más general de descentralización en China, que ha promovido exitosamente el emprendedurismo del gobierno local. Sin embargo, mientras la reforma fiscal les dio a los gobiernos locales mayor control sobre sus ingresos, al mismo tiempo estos han enfrentado mayores responsabilidades en el gasto. Este artículo se propone analizar el proceso de descentralización fiscal que se llevó a cabo a partir de los ochenta y elucidar la racionalización y las consecuencias de ese proceso. Palabras clave. Descentralización fiscal, gobierno local, gobierno central, disparidad regional, ingresos y gastos fiscales, reforma.

\footnotetext{
* Institute for International Studies, University of Technology, Sydney (UTS) ORCID http:// orcid.org/0000-0001-8416-6769
} 


\section{Introduction}

7 iscal decentralization has been an integral part of China's decentralization process, which successfully promoted local government entre1 preneurialism. But while fiscal reform gave governments increasing authority over local revenue, they have also faced increasing expenditure responsibilities. Given centrally imposed fiscal mandates, local governments with low revenue raising capacity are facing increasing budget constraints. Continued political centralization has also influenced expenditure decisions at the local level, pushing officials to prioritize Central policy rather than local needs. Even though the Central Government has recently boosted its redistributive efforts - trying to address the problem of regional inequalitieswithout a fiscal system that allows for a match between revenue capacity and expenditure responsibilities local governments will continue to face growing budget deficits and to practice an inefficient use of resources.

This article aims to analyze the processes of fiscal decentralization that was put in place in the early 1980s, and to elucidate on the rationale and consequences of that process. To do that it will not only deconstruct the decentralization process as it has developed during the almost three decades of reform, but will also draw on the general literature on decentralization, to compare the Chinese experience with that of other developing countries.

\section{Creating a development model}

Since 1978 China has embarked on an economic reform process with an 'unabated zeal for catching up and getting ahead' (Chung 2003, p. 124). Mapping the processes and reconfigurations in that transition has become an important element of scholarly work on reform China. Rapid change has indeed been the main feature of reform, where in two decades a plethora of new economic, social, cultural and political issues have been unfolding. In its transition from a centrally planned towards some form of a market economy China can be said to be creating its own modernization model. Although the reform process has not followed a pre-established blueprint, some authors argue that there are certain elements of the reform process that can be regarded as comprising a model (Lin et al. 1996; Cao et al. 1999; Murrell 2006). They establish institutional innovation, gradualism and decentralization as the most important elements of the Chinese reform experience. Those elements 
of reform have brought crucial changes to two important relationships: that between the Centre and sub-national levels of government and that between state and society.

New organizational and institutional arrangements introduced by economic reform have significantly influenced the Chinese development process, particularly the ways in which different government levels take part in that development. Through administrative and fiscal authority devolution, institutional restructuring has encouraged new regional and local dynamics of change. Both processes created increased incentives for local governments to promote economic growth (Oi 1999; Oi and Walder 1999; Unger and Chan 1999; Duckett 1998, 2001; Zhu 2004). This local government entrepreneurialism swiftly promoted rural industrialization, which became a major engine of economic and urban growth in the first decade of reform. Furthermore, the intersection of the overhauling of the state sector, economic liberalization and the introduction of new economic actors transformed the role of local governments into more regulatory and less hands-on actors.

The new setting for the distribution of power has also been directly manifested in budgeting authority. Agreeing to share its budget authority with provincial governments, the Centre managed to win their support for economic reform, at the same time that it disentangled itself from a wide range of budgetary responsibilities. The Central Government's declining revenue share triggered an ongoing delegation of fiscal responsibilities to lower levels of government. Provincial and local expenditure increased rapidly, as central expenditure and transfers receded. An imbalance between fiscal responsibility and fiscal capacity resulted in great disparities in economic development and in the availability and quality of services, among regions and between urban hierarchies. Uneven development and widening inequalities have indeed become extremely important for understanding local development in the People's Republic of China (P.R.C.) (Wang and Hu 1999).

The growing burden of increased expenditure responsibilities has perhaps been most severely felt by the lowest governmental levels - county, town and townships. Rising revenue shares have not translated into a more adequate level of resources to meet local needs (Blecher and Shue 1996, p. 48). After the implementation of the 1980 fiscal reform local governments have been subject to increasing fiscal responsibilities, which are often not sustainable from the official budget. Local governments have taken up the burden of the provision of most public services and are also responsible for infrastructural 
development, for which transfers from the Central Government have decreased significantly since the start of the reform process.

When tax revenue is insufficient to meet expenditure, local governments have resorted to the use of extra-budgetary revenue, over which they hold almost absolute control and discretion. Other consequences of the financial pressures at the local level have been a series of distortions and inefficiencies in policy implementation, budget allocation, and public service provision (Wang R. 2002; World Bank 2002; Lin et al. 2003). Trying to comply with their newly acquired responsibilities (i.e. to provide nine years of tuition-free compulsory education to all school-age children; to support the health care sector; to pool resources for the pension system; to provide investment for infrastructural development, etc.) local governments are at times pressed to set priorities that bear little relation to local development needs.

Size and position in the urban hierarchy have been other factors directly affecting the speed and quality of local development (Song and Zhang 2002; Chan and Zhao 2002; Zhao et al. 2003; Zhang 2006). The urbanization drive that came with the start of the reform process saw many small cities and towns entering a race to upgrade their administrative classification, in order to gain more power and autonomy over fiscal resources (Chan and Zhao 2002, pp. 102-3), and to speed up authorization from higher government levels for local special development projects (Blecher and Shue 1996, p. 71). Urban hierarchies have thus perpetuated a system of uneven growth across and within regions. Regional and sub-provincial urban hierarchies remain an important determinant of the socio-economic development of urban centres. The role of the state has been particularly crucial in the process of this urban and regional development (Goodman 1989), while the continued state bias favouring cities has widened rural-urban disparities. The urban bias has been a reality since the Maoist era (Chan and Zhao 2002), when state policy_aided by its socialist institutions - transformed urban areas and their citizens into privileged enclaves.

\section{Decentralization and the changing role of local governments}

Since the end of the Maoist period many scholars have attested the need to look at China not as a single unified politico-economic entity, but as a continental state formed by a series of regional economies and local cultures (Goodman 1999, pp. 52-78). Analyses of regional and local dynamics of chan- 
ge have become indispensable when articulating the Chinese development process. Local autonomy for the formulation of local solutions has long been recognized by the Communist leadership as a development imperative for a country of such size and diversity as China. ${ }^{1}$ Regionalization and decentralization policies were first put into place in the PRC during the mid-1950s, as a way to avoid the systemic faults of the command economy based on the Soviet model (Goodman 1989, p. 21). Nevertheless, in the Maoist era-particularly during the Cultural Revolution-local autonomy vis a vis the Centre remained a relative concept, since the Centre continued to maintain the guiding hand in most areas of development through both political and budgetary control.

In the reform era, decentralization programs once again became a crucial element of the modernization process. From the early 1980s, decentralization has been the policy strategy most extensively and intensively implemented at the sub-national level. ${ }^{2}$ As an ongoing process of both political and administrative nature, a more tangible devolution of power to lower governmental levels has taken place. ${ }^{3}$ Local governments are in effect the ones implementing China's development agenda; not only playing a more active role in directing growth and interpreting and mediating economic, social and environmental issues (Skinner et al. 2003), but also carrying a stronger responsibility in making that development more inclusive. Adding to the complexity of the decentralization process is the prevalent influence of the Chinese Communist Party (CCP) ${ }^{4}$ in both government and socio-economic activities (Duckett 2001; Edin 2003; Li 2004; Whiting 2004; Tsui and Wang 2004; Pieke 2004).

1. Decentralization theorists have long argued in favour of decentralization initiatives for heavily populated countries, where sub-national units can be larger than many small countries, both in terms of population and in geographical size. See: Prud'homme 1995, and Tanzi 2000. At the empirical level the relationship between country-size and decentralization has been found to be positive. See: Panizza 1999; Arzaghi and Henderson 2002.

2. Despite this fact, at different stages of the reform process there have been sectoral recentralization shifts. These have been mainly related to revenue collection and to the control of 'strategic' industrial sectors, like the petrochemical and automobile industry. See: Huang 1996, p. 656; and Sun 2001.

3. Devolution refers to the transfer of responsibility for governing, through the strengtheningfinancially and legally — of sub-national units of government (Klugman 1994).

4. Some authors argue that China's continued political centralization has been crucial in promoting local government incentives to actively encourage economic growth. See: Blanchard and Schleifer 2001. Others, however, argue that CCP ultimate control over governance has been responsible for China's boom and bust economic cycles, and detrimental to the overall economy. See: von Pfeil 2004. 
As has been the case in most other countries implementing decentralization processes, the main thrust behind decentralization strategies in China has been the improvement of economic efficiency and the promotion of economic growth. To that end, one of the most important components in the transformation of the Chinese intergovernmental system has been fiscal reform. Devolution of power and resources from the Centre to sub-national governments, and the reallocation of expenditure and revenue responsibilities have dramatically changed the nature of government intervention in economic matters (Baum and Shevchenko 1999). Perhaps the most well known change has been the emergence of a phenomenon described by some as 'local government corporatism' (Nee and Su 1996; Oi 1999) and in various ways by others (Pearson 1997; Duckett 1998; Yep 2000). From the early 1980s, local governments and their local leaders have strengthened their participation in the economic and overall prosperity of their localities, taking the role of entrepreneurs pursuing rapid economic growth (Duckett 2001; Lin et al. 2003; Zhu 2004).

Fiscal decentralization and

From the early 1980s, local governments and their local leaders have strengthened their participation in the economic and overall prosperity of their localities, taking the role of entrepreneurs pursuing rapid economic growth the transfer of an important number of state owned enterprises (SOEs) to local government ownership also contributed to local economic prosperity, by granting local governments a claim over a higher percentage of tax revenues from those industries and allowing for a closer control over their assets and financial resources. At the same time, agricultural decollectivization and the consequent labour surplus in the countryside triggered the development of rural industrialization, which became another major engine of economic growth during the 1980s. During that first decade of reform, township and village enterprises (TVEs) became the most dynamic industrial sector, accounting for 36 per cent of the national industrial output in 1993, up from 9 per cent in 1978 (Che and Qian 1998, p. 1). 
The new distribution of power was also directly manifested in budgeting authority. Up until 1979 the budget system had been highly centralized and relied almost solely on SOEs' profits and revenues, which until the mid-1980s still represented the major source of government income. Budget centralization, however, also meant high Central Government financial responsibilities. At the start of the reform process, sub-national governments were granted authority to approve their own budget and were given more flexibility in expenditure assignments, even though they continued to be restricted by numerous expenditure mandates and other national budget laws regulating expenditure growth rates (Bahl and Martinez-Vazquez 2003, p. 24).

Under the fiscal contracting system implemented in the early 1980s, fixed tax sharing rates between the Central Government and the majority of the provinces had the unintended result of dangerously reducing fiscal revenue for the former. Decreasing fiscal extraction at the centre was also exacerbated by declining SOE revenues and by enterprise ownership diversification, which made tax administration more complex (Blejer 1993; Riskin 2000). Not being accountable for their own losses, SOEs often had little incentive to improve their financial performance. Moreover, ailing SOEs usually received tax reductions, subsidies and special loans, which further increased the financial burden of the Central Government (Ma 1997, p. 445). Central revenues plummeted from a ratio of 32 per cent of GDP in 1978 to 11.6 per cent in 1997 (Lin 2000, p. 477). Between 1980 and 1994, a push and pull struggle over tax between Centre and provinces was clearly reflected in fiscal policy, which oscillated from ad hoc decentralization to a system trying to re-centralize tax collection.

In 1994 the Central Government introduced a more comprehensive fiscal reform, with its most pressing goal being to re-negotiate tax shares with the provinces to reclaim part of the revenue share. It was also a response to growing concerns over divergent tax policy practices across sub-provincial units, as well as an attempt at simplifying the tax system and adapting it to the changing economic conditions. The new tax sharing system (TSS) brought changes not only to tax policy, but also covered tax administration and intergovernmental fiscal relations (Bahl and Martinez-Vazquez 2003; Wong 2000). Expenditure assignment issues, however, were not addressed, which continued the trend of expenditure responsibilities' shift to lower levels of government (Wong and Bird 2005).

As part of the simplification efforts, tax assignment and enterprise income tax across provinces became more uniform, while the number of 
taxes in the system was reduced from 32 to 18 (Bahl and Martinez-Vazquez 2003, pp. 6-7). The top marginal enterprise income tax rate was reduced from 55 per cent to 33 percent, and was applied to all enterprises regardless of ownership. In turn, the value-added tax (VAT) became the single most important source of tax revenue for the Central Government ${ }^{5}$, accounting for 70 per cent of total government revenue in 1995 (Ma 1997, p. 447). Up until 2002 the VAT had been the only shared tax between the Centre and sub-national governments, sharing it at a fixed rate of 75 and 25 per cent respectively (Wong 2000). From that year on, however, local governments have also had to share the enterprise income tax and the individual income tax-previously entirely retained by sub-national governments. ${ }^{6}$ This move has been justified as a strategy to increase the pool of resources available to the Central Government for the equalization transfer system (Bahl and Martinez-Vazquez 2003, p. 27; Martinez-Vazquez et al. 2007). Other revenue assigned to sub-national governments includes the business tax, land use tax, property tax, and other revenues. ${ }^{7}$

The new fiscal arrangements were successful in raising central revenue, helping it increase to a share of 18.7 per cent of GDP by 2002 (Ahmad et al. 2004). Yet, despite this achievement, other problems related to fiscal decentralization were exacerbated. These relate to widening regional inequalities (Kanbur and Zhang 2005), an inefficient equalization system (Bahl and Martinez-Vazquez 2003; Zhang and Martinez-Vazquez 2003; Ahmad et al. 2004), and the lack of a clear and stable assignment of expenditure responsibilities, which results in an increased financial burden for less well-off localities (Ma

5. Other Central Government taxes include: customs duties; consumption tax; income taxes from Central Government owned enterprises, banks and non-bank financial intermediaries; remitted profits, income taxes, business taxes, and urban construction and maintenance taxes of the railroad, bank headquarters and insurance companies; and resource taxes on offshore oil extraction (Wong 2000).

6. The sharing ratio between Central and local governments for these two taxes was 50:50 in 2002, and 60:40 in 2003. No announcement had been made as to whether that sharing rate would be incremental (Zhang and Martinez-Vazquez 2003, p. 12).

7. These include: Urban maintenance and construction tax; property tax; vehicle and vessel utilization tax; VAT on land; stamp tax; agricultural and animal husbandry tax; tax on special produces; contract tax; tax on the occupation of arable land; profit remittances by all locally owned enterprises; revenue from compensation for use of state-owned land; gift and bequest tax; slaughter tax; and reorientation tax on capital construction. Zhang and MartinezVazquez 2003, p. 11. 
and Norregaard 1998; Li 2002; Jun 2002). The following section will discuss some of the consequences from the still incomplete fiscal reform.

The decentralization debate

Decentralization strategies and instruments have long been suggested to promote better and more efficient governance than that provided by centralized systems (Hayek 1945; Tiebout 1956; Musgrave 1959; Oates 1972). According to the theory and its advocates, the strongest case for decentralization lies in its potential for economic efficiency improvement, which can be interpreted in at least three ways: a) allocative efficiency (involving the consideration of what is produced, preferences and how it is allocated between agents); b) technical efficiency (cost minimization), and; c) intemporal allocation of resources (implementation and maintenance) (Klugman 1994). Links have also been made between decentralization and a more efficient provision of public goods and social services, which in turn are said to have positive effects on social development (Rondinelli 1990; Bardhan and Mookherjee 2005). Decentralization is promoted as a way to alleviate local information constraints, leaving local governments to more efficiently address local needs and preferences (Hayek 1945; Faguet 2004). Huther and Shah (1998)—through the development of a governance quality index and using a sample of eighty countries-found empirical evidence that showed governance quality was enhanced by greater decentralization. Lastly, decentralization has been defended for its potential to promote democratization, by facilitating and increasing local participation in political decision-making (Fiszbein 1997; Rossi 1998).

A different set of literature, however, has established that the dangers of decentralization are perhaps more real than its potential; warning of some of the serious drawbacks that badly designed decentralization programs have had (Olowu 1990; Prud'homme 1995). Decentralization has been said to perpetuate and increase inter-regional inequalities (richer local governments will always have higher tax bases), and to have a negative impact on redistribution (Central Government spending declines with fiscal decentralization) (Prud'homme 1995, 2003; Inman and Rubinfeld 1996; Tanzi 2000). Other problems associated with decentralization have been: triggering destructive competition among sub-national governments ${ }^{8}$ to attract investment and

8. Oates, however, states that intergovernmental competition can have beneficial effects by disciplining excessive public spending and other forms of fiscal misbehaviour (Oates 1999, 
enterprises (Prud'homme 1995; Tanzi 2000; Rodriguez-Pose and Gill 2003, p. 31); increasing difficulties in macroeconomic policy implementation (Oates 1972; Prud'homme 1995); severely lowering the quality and quantity of social services (Wong 2002; Li 2002), and; increasing corrupt practices by local officials (Fisman and Gatti 2000; Tanzi and Prakash 2003).

Furthermore, there is the argument that decentralization can only reap positive fruits when wide citizen participation in decision-making is present and when a functioning democratic system is already in place (Hausken et al. 2004). This seems to be the path followed by most developed countries. Empirical evidence on the inverse equation-from decentralization to democratization-however, has been inconclusive (Panizza 1999; Arzaghi and Henderson 2002).

Despite the criticism, the literature falls short of discrediting decentralization, but rather calls for the need to design strategies that suit the specific characteristics and needs of each system (Ebel and Yilmaz 1999; Prud'homme 2003; Rodriguez-Pose and Gill 2003). Recent debates center on optimal degrees of decentralization, the changing role of the central government, and on the instruments that can allow for more efficient market development and better governance (Oates 1999; Cai and Treisman 2004). The different positions argue for various sectors to undergo different degrees of decentralization, with the central government maintaining a strong role over various key issues like: macroeconomic stabilization, redistribution, national defense, and the provision of public goods with substantial spill-over effects. This continuing debate, however, has remained mostly at the theoretical level, leading to a call in the literature for more empirical studies that can aid decentralization program design, while contributing to the development of more effective decentralization measurement instruments (Rodden 2004).

Decentralization thus remains a contested field, one in which various decentralization models continue to be tested and modified based on case studies and cross-country analysis and comparisons, both in the developed and the developing world. Empirical studies have so far given inconclusive evidence about the direct relationship between decentralization and economic growth, efficiency gains, accountability, democratization, and other processes

p. 1141). Following the market preserving federalism model, Montinolla et al. have also argued that inter-jurisdictional competition can have a positive influence on market promotion (1996, pp. 57-60). See also: Brennan and Buchanan 1980. 
associated with decentralization efforts. They have nonetheless aided a better understanding of the complexity and diversity of decentralization (Rodden 2004), and have allowed for the formulation of a set of rules and guidelines that can serve as aiding mechanisms in order to achieve higher rates of success in the implementation of decentralization strategies (Bahl 1998; Oates 1999; Tanzi 2000). As pointed out by Rodden, decentralization should not be understood only as a 'clean transfer of fixed authority or resources from higher to lower governments', but should be analyzed through the causes and effects 'of shared and intertwined fiscal, political, and policy authority' (2004, p. 29). Decentralization hence implies a complex relationship between central and sub-national governments, with a clear demarcation of responsibilities between the two.

\section{Decentralization in the People's Republic of China}

Evidence from China has similarly pointed to the need for a more comprehensive analysis of decentralization, in which the chances of success and failure require to be 'considered in the context of reform of the tax system' but also in the 'wider environment of population, financial sector and other central government policies' (Bahl and Martinez-Vazquez 2003, p. 38). Following Weingast's theory of market-preserving federalism Montinola et al. have described Chinese decentralization as creating the right incentives at all governmental levels to foster economic prosperity, while establishing a range of limits on their behavior (1996, p. 79). Decentralization-in their view-is the strategy by which the government not only preserves and promotes market mechanisms, but is also the process by which the durability of the reform is guaranteed. Li and Lian (1999)—-though agreeing with their model-have a more cynical approach to that symbiotic interaction between the Central and local governments for the supposed promotion of markets and economic growth. They prefer to describe the Chinese system as market-preserving authoritarianism, where Party-State support for economic decentralization becomes the most efficient and credible way not only for catching up with developed countries but also for holding on to power (Li and Lian 1999, pp. 167, 184-6). Blanchard and Schleifer corroborate Li and Lian's argument, stating that political centralization has been the most crucial ingredient by which China was able to reap the economic benefits of decentralization (2001, p. 11). Whatever the means, the image that emerges from these two models is 
one of a fairly decentralized economic and administrative system resembling that of a federal state, though with a strong political centralization.

The Chinese Government would probably like to think of the process of economic reform as resembling the neatly designed top-down decentralization model described by Montinola et al. (1996). Chinese decentralization strategies and processes, however, present a more complex landscape, one in which counterintuitive behaviors - developmental, predatory and entrepreneurial —on the part of the different government levels coexist (Tsai 2004, p. 5). These behaviors have a lot to do with the experimental and gradual nature of reform, to the hierarchical system still prevalent across government levels, and to the different incentives each of those levels of government has been facing since the start of reform. Some have questioned the functionality of the much publicized decentralization achievements, arguing the Party-State has retained a substantial degree of centralization through vertical control over sub-national governments (Tsui and Wang 2004). That control has been exercised in a direct fashion through the imposition of fiscal mandates, and more indirectly-but perhaps more efficiently-through both the cadre responsibility system (gangwei zerenzhi) and the target responsibility system (mubiao zerenzhi) (Edin 2003; Tsui and Wang 2004; Whiting 2004). Some authors have gone as far as to state that the nomenklatura system of personnel management of the CCP is in fact the most important institution reinforcing national unity (Naughton and Yang 2004).

In his seminal work Centre and Province in the People's Republic of China Goodman analyses the complexity of power balancing between the Centre and the provinces during the first decentralization campaign in the late 1950s, and highlights the extent to which the Centre-local power struggle has been a recurrent problem throughout Chinese history (1986, p. 4). The reform era is no exception, though this time the centrifugal forces triggered by decentralization and economic reform have created a more complex power contest: one in which the Centre-province duality is complicated by regional economic disparities, which have tipped political leverage to the more developed coastal areas. According to Bahl and Martinez-Vazquez decentralization and the newly gained economic power of some provincial and sub-provincial governments (especially those in the coastal areas) have on the one hand counterbalanced the power of the Central Government (helping preserve the reform process), but on the other hand have weakened the Centre's ability to implement equalization policies (2003, pp. 18-9). Their increased bargaining 
power has secured rich provinces a substantial share of revenue, diminishing funds for redistribution.

Although there is certainly growing concern by the Centre regarding regional inequalities, fiscal policy does not seem to acknowledge the varying capabilities of sub-national governments across regions and government hierarchies. Intergovernmental fiscal relations necessarily take place in that same hierarchical structure; one in which provinces have different revenue raising capacities, and where lower governmental levels have less bargaining power vis a vis the government level immediately on top. A further complication is the fact that the tax sharing system only binds the Central and provincial governments, but does not establish a working system for sub-national fiscal relations. To a great extent sub-national intergovernmental fiscal relations have resembled those between the Centre and the provinces (Bahl and Wallich 1992), but the lack of a binding framework has weakened the bargaining power of those governments at the bottom of the hierarchy.

Provincial budget flexibility, in turn, constrains 'local government revenue autonomy, reduces intergovernmental accountability, cuts revenue predictability of local governments, and reduces incentives for revenue-mobilization' (Zhang and Martinez-Vazquez 2003, p. 17). The 1994 TSS further aggravated the situation by re-centralizing revenue at the Centre, while setting off a parallel centralization trend at the provincial level (Wong 2002). Tax recentralization trends, together with increased responsibility delegation have consequently put a heavy burden on county, town and township governments. Han Jun has rightly described the financial situation of those local governments as facing the plight of 'cooking a meal without rice' (2002, p. 6).

Following the argument that in any complex economy the patterns of financial authority are a reflection of power distribution among the various governmental levels (Blecher and Shue 1996, p. 46), then China could be said to be a highly decentralized country. Operating in many ways as a de facto federal system - though remaining a unitary state-Chinese sub-national governments are now responsible for around 70 per cent of total government expenditures, with counties accounting for 40 to 50 per cent of sub-national spending (Wong 2002). These figures, however, give a misguided picture of the relative power of local governments. Even though sub-national governments have won autonomy over budget authorization, they lack formal revenue raising powers, are not able to modify tax rates and tax bases set 
by the Central Government, while being subject to several expenditure laws and mandates. ${ }^{9}$

Constraining mandates not only have increased the financial burden of local governments, but have also made the assignation of budgetary funds more inflexible. Partly as a legacy of the planning system and partly as a result of the financial squeeze, allocation of funds by local governments usually follows the principle of 'budgeting incrementalism', based on the previous year's budget or on an average from the previous five years (Wang, R. 2002, p. 5). Moreover, local governments often have no mechanisms to ascertain local needs and demands, which results in a mismatch between budget fund allocation and actual local needs (Wang, R. 2002, p. 19). At the same time, local officials' incentives for action are being increasingly shaped by centrally imposed personnel performance evaluation systems, at times more so than by wider local needs. It is important to note that central policies are not, however, always at odds with local developmental needs.

And while revenue assignments have been clearly delineated in the Budget Law, expenditure assignments remain much more blurry, and are consonantly being changed. According to Bahl's Implementation Rules for Fiscal Decentralization, expenditure needs should be established before tackling the question of revenue assignments, in order to allow for a more economically efficient assignment of funds $(1999$, p. 5). Those most affected by the lack of clarity in expenditure responsibilities have been sub-provincial governments, which due to the ongoing delegation of fiscal responsibilities to their jurisdictions ${ }^{10}$, have experienced growing budget deficits (Jun 2002; Yep 2004).

The realization that formal revenue mechanisms cannot provide sufficient funds to cover for the financial responsibilities of local governments have lead local officials to increasingly rely on alternative revenue sources, a practice Bahl (1999) has described as 'backdoor federalism'. Although not included

9. The legal framework of public budgeting is contained in the Budget Law enacted by the Central Government in 1994.

10. A major burden for county and township governments has been the compulsory salary increases for civil servants mandated by the Central government. Cases where government offices and SOEs do not even have enough resources to pay for staff's salaries are also commonplace. This was something that constantly came up in interviews during fieldwork carried out by the author in Hongtong County, Shanxi Province in October 2003. Other studies have documented cases of county governments delaying salary payments to their staff or not paying them their full salary amount (See: Jun 2002). 
in the formal budget tabulation, extra budgetary and off-budget revenues ${ }^{11}$ have become an integral part of local governments' budgets. In the last two decades, extra budgetary revenues have been growing at a much faster pace than formal tax revenues. According to World Bank figures, in 2002 the overall budget of China represented 14 per cent of Gross Domestic Product (GDP), whereas extra budgetary revenues accounted for as much as 20 per cent of the GDP (World Bank 2002).

\section{Conclusions}

Decentralization should be conceived as a trade-off between possible benefits and costs (Bahl 1999, p. 2). The Chinese leadership had a clear vision of the goals and benefits it wanted to achieve through decentralization, but the costs of decentralizing the system were either underestimated or not even considered ( $\mathrm{Li}$ and Lian 1999, p. 174). In the case of tax reform, one of the negative consequences of fiscal decentralization was the worsening of inequalities along regional lines, between rural and urban areas, and amongst the various government levels. Often only governments in economically more dynamic areas have tax bases that allow them to meet the expenditure mandates imposed by the Central Government. Local governments in less developed areas of the country, and those at the lower end of the administrative hierarchy (small cities, counties, towns and townships) have found it increasingly difficult to raise enough revenue to meet their expenditure responsibilities. At the same time, the ways in which fiscal policies influence expenditure practices at the local level has direct consequences for their socio-economic development. Given the continued political centralization in China, when tax revenues are scarce local government officials are more likely to use those resources in projects that ill enhance their political career, without consideration of local needs.

11. For legal purposes these two revenue categories are not regarded as taxes. The former is a revenue category used by both the Centre and local governments. In theory, extra budgetary impositions need to get official authorization from one or more offices of the Ministry of Finance, though many of those charges are seldom put forward for approval. Off-budget revenues are an even more complicated category. They include a wide range of fees that are meant to generate funds for different local government initiatives and projects. Off-budget revenues, however, need not get approval from or be reported to financial departments; being therefore only subject to the discretion of local officials (Eckaus 2003, p. 74-5). 
Many local governments have resorted to the imposition of fees outside the formal taxation system. Although this extra-budgetary revenue gives local government some 'breathing space' to meat expenditure responsibilities, they are also prone for misuse by government officials. Throughout the 1980s and until 1994, fiscal reform in China developed in an ad hoc manner, with changes coming mostly as a response to issues arising from the incomplete nature of the economic reform process, but also increasingly from external constraints of binding international treaties (Li and Lian 1999; Bahl and Martinez-Vazquez 2003; He 2008). Policy formulation has gradually become more responsive to the new economic setting, but continues to favor experimentation and gradual reform, which in some instances limits the full potential of productive forces. Since the 1994 fiscal reform the Central Government has been able to curve local government practices of extra-budgetary fee imposition and has strengthened its redistributive capacity. However, it has been unwilling to settle the boundaries over expenditure responsibilities. Without a clear demarcation of those responsibilities local governments will continue to bear a growing expenditure burden, which will in turn continue to hinder a more efficient use of resources, and continue to negatively affect investment in areas such as public services provision and social safety nets. my

\section{References}

AhmAD, Ehtisham; Singh, Raju; and Fortuna, Mario 2004, 'Toward More Effective Redistribution: Reform Options for Intergovernmental Transfers in China', IMF Working Paper WP/04/98 (June).

ARzaghi, Mohammad and Henderson, Vernon 2002, 'Why Countries Are Fiscally Decentralizing', Department of Economics, Brown University (Dec.).

BARDHAN, Pranab and Mookherjee, Dilip 2005, 'Decentralizing antipoverty program delivery in developing countries', Journal of Public Economics, vol. 89, no. 4.

BAHL, Roy 1999, 'Implementation Rules for Fiscal Decentralization', paper presented at the International Seminar on Land Policy and Economic Development, Taiwan (Nov. 17).

BAHL, Roy and Martinez-Vazquez, Jorge 2003, 'Fiscal Federalism and Economic Reform in China', Working Paper 03-13 Andrew Young School of Policy Studies, Georgia State University (May). 
BAHL, Roy and Wallich, Christine 1992, 'Intergovernmental Fiscal Relations in China', World Bank Policy Research Working Paper Series No. 1122.

BAUM, Richard and Shevchenko, Alexei 1999, 'The "State of the State"'. In: Goldman, Merle and MacFarquhar, Roderick (eds), The Paradox of China's Post-Mao Reforms, Harvard University Press.

Blecher, Marc and Shue, Vivienne 1996, Tethered Deer. Government and Economy in a Chinese County, Stanford University Press.

Blejer, Mario 1993, 'China: Prolonged Reforms and the Weakening of Fiscal Control'. In: Tanzi, Vito (ed), Transitions to Market: Case Studies in Fiscal Reform, International Monetary Fund.

CAI, Hongbin and Treisman, Daniel 2004, 'State Corroding Federalism', Journal of Public Economics, vol. 88, no. 3-4.

CHAN, Roger C.K. and Zhao, X.B. 2002, 'The relationship between administrative hierarchy position and city size development in China', GeoJournal, vol. 56, no. 2.

CHE, Jiahua and Qian, Yingyi 1998a, 'Insecure Property Rights and Government Ownership of Firms, Quarterly Journal of Economics, vol. 2, no. 2.

Chung, Jae Ho 2003, 'China's Reforms at Twenty-five: Challenges for the New Leadership', China: An International Journal, vol. 1, no. 1 (March).

Ducketт, Jane 2001, 'Bureaucrats in Business, Chinese Style: The Lessons of Market Reform and State Entrepreneurialism in the People's Republic of China', World Development, vol. 29, no. 1.

Ducketт, Jane 1998, The Entrepreneurial State in China, Routledge.

EBEL, Robert D. and Yilmaz, Serdar 1999, 'Intergovernmental Relations: Issues in Public Policy', paper presented at the Forum on Fiscal Decentralization in Bosnia and Herzegovina, Sarajevo 14-16 June.

EdIN, Maria 2003, 'State Capacity and Local Agent Control in China: CCP Cadre Management from a Township Perspective', The China Quarterly, no. 173 (March).

FAGUeT, Jean-Paul 2004, 'Does Decentralization Increase Responsiveness to Local Needs? Evidence from Bolivia', Journal of Public Economics, vol. 88, nos. 3-4.

FISMAN, Raymond and Gatti, Roberta 2000, 'Decentralization and Corruption: Evidence from Across Countries', World Bank Policy Research Working Paper Series No. 2290 (Feb.).

FISZBEIN, Ariel 1997, 'The emergence of local capacity: lessons from Colombia', World Development, vol. 25, no. 7. 
Goodman, David S.G. 1999, 'King Coal and Secretary Hu: Shanxi's Third Modernisation'. In: Hendrischke, Hans and Feng, Chongyi (eds), The Political Economy of China's Provinces, Routledge.

Goodman, David S.G. (ed) 1989, China's Regional Development, Routledge for the Royal Institute of International Affairs: London.

Goodman, David S.G. 1986 Centre and Province in the People's Republic of China, Cambridge University Press.

Hausken, Kjell; Martin, Christian W.; and Plumper, Thomas 2004, 'Government Spending and Taxation in Democracies and Autocracies', Constitutional Political Economy, vol. 15, no. 3.

HaYeK, Friedrich 1945, 'The Use of Knowledge in Society', American Economic Review, vol. XXXV, no. 4 (Sept.).

HE, Liping 2008, 'Has Fiscal Federalism Worked for Macroeconomic Purposes? The Chinese Experience 1994-2003', China \& World Economy, vol. 16, no. 1.

Huther, Jeff and Shah, Anwar 1998, 'A simple measure of good governance and its application to the debate on the appropriate level of fiscal decentralization', World Bank Policy Research Working Series No. 1894 (March).

InMAN, Robert P. and Rubinfield, Daniel L. 1996, 'The Political Economy of Federalism', In: Mueller, Dennis (ed), Perspectives on Public Choice, Cambridge University Press.

Jun, Han 2002, 'Public Finance Crises in Chinese Counties and Towns: Performance, Causes, Impact and Measures', paper presented at the International Workshop on China's Rural Public Finance, Beijing 7 Dec.

Kanbur, Ravi and Zhang, Xioabo 2005, 'Fifty Years of Regional Inequality in China: a Journey Through Central Planning, Reform, and Openness', Review of Development Economics, vol. 9, no. 1.

KLUGMAN, Jeni 1994, 'Decentralization: a survey of literature from a human development perspective', UNDP Occasional Paper.

LI, Bingqin 2004, 'Urban Social Exclusion in Transitional China', Centre for Analysis of Social Exclusion Paper 82.

LI, Junsheng 2002, 'Lopsided Regional Economic Development and Extremely Inequitable Public Services in China: Problems and Countermeasures', World Bank background material for the course on 'Decentralization and Intergovernmental Fiscal Reform in East Asia', Bangkok, Thailand, 6-7 June. 
LI, Shuhe and Lian, Peng 1999, 'Decentralization and coordination: China's credible commitment to preserve the market under authoritarianism', China Economic Review, vol. 10, no. 2.

LIN, Shuanglin 2000, 'The decline of China's budgetary revenue: reasons and consequences', Contemporary Economic Policy, vol. 18, no. 4.

LiN, Justing Y. L.; Cai, Fang; and Zhou, Li 1996, 'The Lessons of China's Transition to a Market Economy', The Cato Journal, vol. 16, no. 2.

LiN, Justin Yifu; Tao, Ran; and, Liu, Mingxing 2003, 'Decentralization and Local Governance in the Context of China's Transition', Center for Chinese Agricultural Policy Working Paper 03-E3.

MA, Jun 1997, 'China's Fiscal Reform: An Overview', Asian Economic Journal, vol. 11, no. 4.

MA, Jun and Norregaard, John 1998, 'China's Fiscal Decentralization', IMF external publication.

MARTINeZ-VAZQUeZ, Jorge; Qiao, Baoyun; and, Zhang, Li 2007, 'The Role of Provincial Policies in Fiscal Equalization Outcomes in China', International Studies Program, Working Paper 07-05, Andrew Young School of Policy Studies, Georgia State University (March).

Montinolla, Gabriella; Qian, Yingyi; and Weingast, Barry R. 1996, 'Federalism, Chinese Style: The Political Basis for Economic Success', World Politics, vol. 48, no. 1.

Murrell, Peter 2006, 'Institutions and Transition'. In: Blume, Laurence and Durlauf, Steven (eds), The New Palgrave Dictionary of Economics, $2^{\text {nd }}$ Edition, Palgrave Macmillan.

Musgrave, Richard A. 1959, The Theory of Public Finance, McGraw-Hill.

NeE, Victor and Su, Sijin 1996, 'Institutions, Social Ties, and Credible Commitment: Local Corporatism in China'. In: McMillan, John and Naughton, Barry J. (eds), Reforming Asian Economies: The Growth of Market Institutions Ann Arbor, University of Michigan Press.

OAtes, Wallace E. 1999, 'An Essay on Fiscal Federalism', Journal of Economic Literature, vol. 37, no. 3.

OAtes, Wallace 1972, Fiscal Federalism, Harcourt Brace Jovanovich: New York.

OI, Jean C. 1999, Rural China Takes Off. Institutional Foundations of Economic Reform, University of California Press.

OI, Jean C. and Walder, Andrew G. (eds) 1999, Property Rights and Economic Reform in China, Stanford University Press. 
Olowu, Dele 1990, 'The Failure of Current Decentralization Programs in Africa'. In: Wunsch, James and Olowu, Dele (eds), The Failure of the Centralized State, Westview Press.

Panizza, Ugo 1999, 'On the determinants of fiscal centralization: Theory and evidence', Journal of Public Economics, vol. 74, no. 1.

Pearson, Margaret M. 1997, China's New Business Elite, Stanford University Press.

Pieke, Frank N. 2004, 'Contours of an anthropology of the Chinese State: Political structure, agency and economic development in rural China', Journal of the Royal Anthropological Institute, vol. 10, no. 3.

Prud'homme, Remy 2003, 'Fiscal Decentralization in Africa: A Framework for Considering Reform', Public Administration and Development, vol. 23, no. 1.

Prud'homme, Remy 2000, 'Patterns and Prospects in China's Urbanization Strategy', paper presented at the Workshop on China's Urbanization Strategy: Opportunities, Issues, and Policy Implications, sponsored by the State Planning Commission, the Chinese Ministry of Construction and the World Bank.

Riskin, Carl 2000, 'Decentralization in China's Transition', Bratislava Policy Paper No. 4, UNDP.

RoDDEN, Jonathan 2004, 'Comparative Federalism and Decentralization: On Meaning and Measurement', Comparative Politics, vol. 36, no. 4.

Rodriguez-Pose, Andres and Gill, Nicholas 2003, 'The global trend towards devolution and its implications', Environment and Planning C, vol. 21, no. 3.

Rondinelli, Dennis A. 1990, 'Decentralization, Territorial power and the state: A Critical Response', Development and Change, vol. 21, no. 3.

RossI, Marco 1998, 'Decentralization Initial Experiences and Expectations of the SDC', Swiss Agency for Development and Cooperation.

Skinner, Mark W.; Joseph, Alun E.; and, Kuhn, Richard G. 2003, 'Social and environmental regulation in rural China: bringing the changing role of local government into focus', Geoforum, vol. 34, no. 2.

SonG, Shunfeng and Zhang, Kevin Honglin 2002, 'Urbanization and City Size Distribution in China', Urban Studies, vol. 39, no. 12.

TANZI, Vito 2000, 'On Fiscal Federalism: Issues to Worry About', paper presented at the Conference on Fiscal Decentralization sponsored by the IMF Fiscal Affairs Department (FAD), Nov. 20-21. 
TANZI, Vito and Prakash, Tej 2003, 'The cost of government and the misuse of public assets'. In: Martinez-Vazquez, Jorge and Alm, James (eds), Public Finance in Developing and Transitional Countries: Essays in Honor of Richard Bird, Edward Elgar Publishers.

Tiebout, Charles 1956, 'A Pure Theory of Local Expenditures', The Journal of Political Economy, vol. 64, no. 5. (Oct.).

TsaI, Kellee S. 2004, 'Off Balance: The Unintended Consequences of "Fiscal Federalism" in China', Journal of Chinese Political Science, vol. 9, no. 2.

Tsui, K. and Wang, Y. 2004, 'Between separate stoves and a single menu: Fiscal decentralization in China', The China Quarterly, no. 177 (March).

UnGER, Jonathan and Chan, Anita 1999, 'Inheritors of the boom: private enterprise and the role of local government in a rural South China township', The China Journal, no. 42 (July).

WANG, Rong 2002, 'Political Dimensions of County Government Budgeting in China: a case study', Institute of Development Studies Working Paper 166 (Oct.).

WANG, Shaoguang and Hu, Angang 1999, The Political Economy of Uneven Development: The Case of China, M E Sharpe.

Whiting, Susan H. 2004, 'The Cadre Evaluation System at the Grass Roots: The Paradox of Party Rule'. In: Naughton, Barry J. and Yang, Dali L. (eds), Holding China Together. Diversity and National Integration in the PostDeng Era, Cambridge University Press.

Wong, Christine 2000, 'Central-local Relations Revisited: the 1994 Tax Sharing Reform and Public Expenditure Management in China', paper presented at the international conference on Central-Periphery Relations in China: Integration, Disintegration or Reshaping of an Empire?, Chinese University of Hong Kong, March 24-25.

Wong, Christine and Bird, Richard 2005, 'China's Fiscal System: A Work in Progress', Working Paper 05-20 Andrew Young School of Policy Studies, Georgia State University (Nov.).

WORLD BANK 2002, 'China national development and sub-national finance: a review of provincial expenditures', Report 22951-CHA.

Yep, Ray 2004, 'Can "Tax-for-Fee” Reform Reduce Rural Tension In China? The Process, Progress and Limitations', The China Quarterly, no. 177 (March). 
YeP, Ray 2000, 'The Limitations of Corporatism for Understanding Reforming China: an empirical analysis in a rural county', Journal of Contemporary China, vol. 9, no. 25.

ZHANG, Xiaobo 2006, 'Fiscal Decentralization and Political Centralization in China. Implications for growth and inequality', UNI-WIDER Research Paper No. 2006/93 (August).

ZHANG, Zhihua and Martinez-Vazquez, Jorge 2003, 'The System of Equalization Transfers in China', Working Paper 03-14 Andrew Young School of Policy Studies, Georgia State University (July).

ZHAO, Simon X.B.; Chan, Roger C.K.; and Sit, Kelvin T.O. 2003, 'Globalization and the dominance of large cities in contemporary China', Cities, vol. 20, no. 4.

ZHU, Jieming 2004, 'Local Developmental State and Order in China's Urban Development During Transition', International Journal of Urban and Regional Research, vol. 28, no. 2. 